\title{
Learning Organization Practices and Job Satisfaction among Academicians at Public University
}

\author{
Murni Zarina Mohamed Razali, Nurul Aufa Amira, and Nor Diyana Mohammed Shobri
}

\begin{abstract}
The purpose of this study was to examine the relationship between learning organization practices and job satisfaction among academicians at public university. The primary objective of this study was to describe the practices of learning organization among academicians and how it may influence their job satisfaction at public university. Correlation research design has been applied in the study where questionnaire was used as the instrument. Based on the data gained in this study, it shows that strategic leadership was the most dimensions which the academicians prefer to practise while encourage collaboration and team learning is the lowest practised dimension. From the findings, it revealed that there is a positive relationship between learning organization practices and job satisfaction among the academicians. In future research, academicians from private universities can be study as comparison with public universities academicians. Such comparisons will help in generating strategic plans to narrow down the performance gap between two sectors and get the most out of the potency in learning.
\end{abstract}

Index Terms-Job satisfaction, learning organization, academicians.

\section{INTRODUCTION}

Today, many organizations are undergoing a fundamental of change that forced by globalisation, technology advancement, diversity workforce and knowledge retention. The best way to adapt these changes is to practise learning organization as part of the organization culture. The concept of learning organization has attracted attention from leading management and organizational behaviour. The concept that has been introduced by Peter Senge in 1990 [1] explained that learning organization is the organizations where people continually expand their capacity to create the results they truly desire, where new and expansive pattern thinking nurtures, collective aspiration is set free and where people are continually learning how to learn together. Learning organization also been understood as an organization in which people at all levels, individually and collectively increasing capacity to produce result continuously [2]. According to Giocomazzi \& Steiner [3], the term learning organization is a symbol for the ability of the organization to become more capable in the delivery of its products, but in a specific way.

By practising learning organization, it would help the organization to react quickly and adjust their behaviours appropriately in certain situation. Senge has overviewed the practice and theory of learning organization in term of "five discipline" included personal mastery, mental models, shared

Manuscript received May 20, 2013; revised July 22, 2013.

Murni Zarina Mohamed Razali is with the University of Technology Mara, Malaysia (e-mail: murnizarina@puncakalam.uitm.edu.my). vision, team learning and system thinking. However, in 1996, Watkins and Marsick [4] has identified seven feature of learning organization that are continuous learning opportunities, inquiry and dialogue, collaboration and team learning, system to capture and share learning, a collective vision, connection to company's environment and strategic leadership for learning. In year 2003, based on the seven features of learning organization, Watkins and Marsick [5] come out with the new model that stated learning organization components can be divided into three. First component consists of system level and continuous learning, second component is learning then generates and manages knowledge outcomes and third components is the outcomes that lead to organization's performance and value.

This concept has attracted attention from most of leading management and organizational behaviour thinkers [6]. It also has attracted attention of education institutions since Sugarman \& College [7] agreed that learning organization has great importance for the worlds of education, business and non-profit management. Differ from the concept like knowledge management, the idea of organizational learning that produce learning organization is likely to be one which sits easily with staff within a university [8]. Learning organization is profitable to be practiced and definitely link to positive outcome such as job performance and job satisfaction [9].

However, in universities according to White \& Weathersby [10] even academicians was rarely practice the simplest theories found in learning organization concept. This circumstances was due to the culture of institution that more on ranking competition, authoritarian and hierarchical structures and acceptance or rejection.

Since there are problems about learning organization practices in higher education institution, the researcher was interested to initiated empirical study specifically on learning organization practices and its influence on job satisfaction among academician.

Therefore, the objectives of this study are as follow:

- To determine the practices of learning organization among academician.

- To determine the level of job satisfaction among academician.

- To examine the relationship between each learning organization practices and job satisfaction among academician.

\section{LITERATURE REVIEW}

\section{A. Learning Organization at University}

In university that assume as learning organization since 
eleventh century, the concept learning organization also been discussed [11]. Both explicitly and implicitly, universities built the importance of learning at an individual level, and create the idea of learning as the fundamentals of development within universities. In fact, the skills and high level of manpower that need for notion development were produced by universities. University is learning organization, which is an organization where all staff members learn continuously to gain new knowledge and possess skills and use their learning to advance both individual and organizational interest, while teaching students to learn how to learn [1],[12]-[14]. In responding towards the globalization era and new advancement of technology, university are now practising learning organizational culture. University is a place where new knowledge are discussing everyday which educators and students are together learn and share the knowledge. They will continually learn and develop required skills, so it will help them to improve their performance and satisfaction.

Martin [15] conducted a case study of how university staffs have experienced changes in academic work in recent years. Data were taken from an international survey of 160 staff members from the United Kingdom and Australia in 1996 - 1997. The staffs were found to feel undervalued in teaching; their universities are lacking in vision and direction and the lack of acknowledgement of their value as professionals and individuals. They also felt discouraged by lacking of collegiality and collaboration between the university and the staff itself. As a result, they become resentful towards their accountability and more become pressure in order to ensure their professional knowledge is not obsolete.

\section{B. Learning Organization and Job Satisfaction}

Job satisfaction is commonly defined as the extent to which employees like their work [16]. According to McShane, Olekalns \& Travaglione [17], job satisfaction can be defined as a person's evaluation of his or her job and work context. It is an evaluation towards job characteristics, work environment and emotional experiences at work. Rowden and Conine [18] examined that, workplace learning has positive impact on job satisfaction in small US commercial banks and found that the workplace learning has positive relationship with job satisfaction. It is also supported by Egan, Yang \& Barlett [19], organizational learning culture positively correlates with employees' job satisfaction. The apparent logic is that employees who are satisfied with their job tend to be cooperative, helpful, respectful and considerate, hence deliver an excellent job [20]. It also found that, environment connection, strategic leadership and embedded system were significantly related to the level of job satisfaction [21]. Here, it shows that learning organization will significantly influence the level of employees' satisfaction and performance. Thus, learning organization could be a strategy for the organization to retain their workforce and to encourage their workers to be more competitive, openness and innovative due to any changes.

\section{Conceptual Framework}

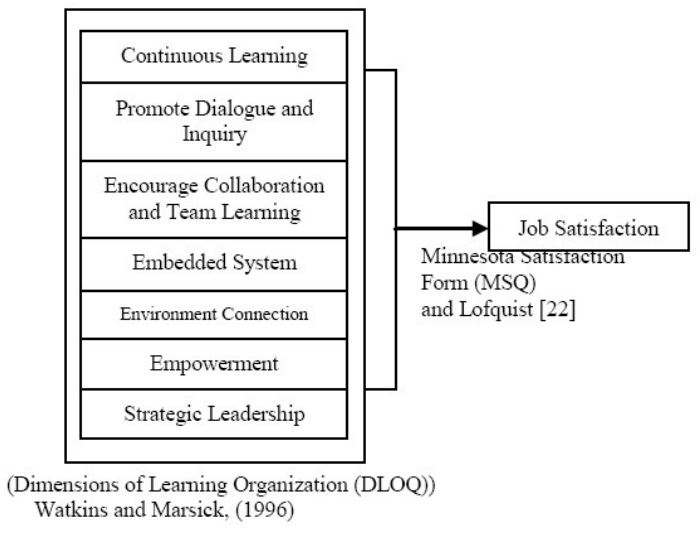

Fig. 1. Theoretical framework

\section{RESEARCH METHODOLOGY}

The type of research design selected for this study was correlational research. This research design is suitable because it examined the relationship between two variables, which are learning organization practices and job satisfaction.

\section{A. Sample and Procedure}

The sampling frame in this study was obtained from the Human Resources Department of two faculties available at University of Technology Mara, Puncak Alam, Selangor, Malaysia. The sampling technique used was simple random sampling where from a population of 200 academic staffs, 134 of them were the respondents of the study.

\section{B. Data Analysis Method}

The researcher used a set of questionnaire to collect data for this study. Statistical analysis was run using the Social Science Software (SPSS) Version 17.0. The analysis was performed in two stages. (See Table I)

TABLE I: DATA ANALYSIS OF STUDY

\begin{tabular}{|c|c|c|c|}
\hline $\begin{array}{l}\text { Research } \\
\text { Objectives }\end{array}$ & Measurement & Scale & Statistic \\
\hline $\begin{array}{l}\text { To determine the } \\
\text { practices of learning } \\
\text { organization among } \\
\text { academician. }\end{array}$ & $\begin{array}{l}\text { RQ1: What are } \\
\text { the scores for } \\
\text { dimensions of } \\
\text { learning } \\
\text { organization? }\end{array}$ & Interval & $\begin{array}{l}\text { Mean and } \\
\text { Standard } \\
\text { Deviation }\end{array}$ \\
\hline $\begin{array}{l}\text { To determine the } \\
\text { level of job } \\
\text { satisfaction among } \\
\text { academician. }\end{array}$ & $\begin{array}{l}\text { RQ2: What is the } \\
\text { level of job } \\
\text { satisfaction } \\
\text { among } \\
\text { academician? }\end{array}$ & Interval & $\begin{array}{l}\text { Mean and } \\
\text { Standard } \\
\text { Deviation }\end{array}$ \\
\hline $\begin{array}{l}\text { To examine the } \\
\text { relationship between } \\
\text { each learning } \\
\text { organization } \\
\text { practices and job } \\
\text { satisfaction among } \\
\text { academician. }\end{array}$ & $\begin{array}{l}\text { RQ3: What is the } \\
\text { relationship } \\
\text { between each LO } \\
\text { practices and job } \\
\text { satisfaction. }\end{array}$ & Interval & $\begin{array}{l}\text { Paerson } \\
\text { Product } \\
\text { Moment } \\
\text { Correlation } \\
\text { Coefficient }\end{array}$ \\
\hline
\end{tabular}

The initial stage of the analysis involved conduction an 
exploratory data analysis to examine the data before any specific statistical procedures was used to analyze them. An exploratory data analysis was conducted to identify any data entry errors and outliers, examine patterns within data and test for assumptions. The second stage involved statistical procedures to answer the research questions. The method employed was correlation analysis to measure the significant relationship between the variables. Correlation analysis happens between the relationships of two variables [23]. The Pearson Product Moment Correlation Coefficient is appropriate for interval and ration called variables [24].

\section{FINDINGS}

\section{A. Profile of Respondents}

Section A of the questionnaire was designed to collect the demographic background pertaining gender, age, years of working experience and respondents' faculty.

TABLE II: PROFILE OF RESPONDENTS ( $\mathrm{n}=134)$

\begin{tabular}{|c|c|c|}
\hline \multicolumn{3}{|c|}{ Gender } \\
\hline & Frequency & Percent \\
\hline Female & 81 & 60.4 \\
\hline Male & 53 & 39.6 \\
\hline \multicolumn{3}{|c|}{ Age } \\
\hline 20-30 ears old & 62 & 46.3 \\
\hline 31-40 ears old & 43 & 32.1 \\
\hline 41-50 ears old & 20 & 14.9 \\
\hline 50 years \&above & 9 & 6.7 \\
\hline \multicolumn{3}{|c|}{ Years of Working Experience } \\
\hline $1-5$ years & 59 & 44.0 \\
\hline $6-10$ ears & 33 & 24.6 \\
\hline $11-16$ ears & 19 & 14.2 \\
\hline 17 years and above & 23 & 17.2 \\
\hline \multicolumn{3}{|c|}{ Respondents' Faculty } \\
\hline $\begin{array}{l}\text { Faculty of Health } \\
\text { Science }\end{array}$ & 76 & 56.7 \\
\hline $\begin{array}{l}\text { Faculty of Business } \\
\text { Mgt }\end{array}$ & 58 & 43.3 \\
\hline
\end{tabular}

Table II shows that $60.4 \%$ of the respondents were female compared to male respondents that only $39.6 \%$. It was found that majority of the respondents were between the ages of 20-30 years that were $46.3 \%$. In terms of years of working experience, $44 \%$ of respondents have 1-5 years working experience, $24.6 \%$ between $6-10$ years experience, $14.2 \%$ of respondents have 11-16 years of working experience and followed by those who working for 17 years and above in the university. For the respondents' affiliation faculty, 56.7\% of the respondents from Faculty of Health Science and 43.3\% were from Business Management.

\section{B. Factor Analysis}

The practices of the learning organization instrument that being used in this study were from the pilot test. The researcher has used factor analysis to analyze the instrument whereas 42 items divided into seven dimensions of learning organization. It also included overall job satisfaction that has been tested in the factor analysis. In factor analysis, principal axis factoring with varimax rotation was performed. All 51 items were tested on coefficient with values less than 0.32 was absolute suppressed.

Steps were taken to reduce the number of item loading. First step were tested on Kaiser-Mayer Olkin Measure of Sampling Adequacy where values at 0.85 were adequate enough to accept the items tested. The outputs from Anti-image Covariance were analyzed. Third steps are analyzing the extraction from communalities values less than 0.1 . Therefore, the researcher deleted 14 items from instrument that has multiple high loading.

\section{Reliability Statistic}

TABLE III: REABILITY STATISTIC

\begin{tabular}{lcc}
\hline \hline Variables & No.of.Items & $\begin{array}{l}\text { Cronbach's } \\
\text { Alpha }\end{array}$ \\
\hline $\begin{array}{l}\text { Continuous } \\
\text { learning }\end{array}$ & 4 & 0.746 \\
$\begin{array}{l}\text { Promote dialogue } \\
\text { \& Inquiry }\end{array}$ & 6 & 0.819 \\
$\begin{array}{l}\text { Encourage } \\
\text { collaboration } \begin{array}{l}\text { team learning } \\
\text { Embedded system }\end{array}\end{array}$ & 4 & 0.874 \\
$\begin{array}{l}\text { Empowerment } \\
\text { Environment } \\
\text { connection }\end{array}$ & 4 & \\
$\begin{array}{l}\text { Strategic } \\
\text { leadership }\end{array}$ & 4 & 0.794 \\
Job satisfaction & 3 & 0.783 \\
\hline \hline
\end{tabular}

Table III, shows the reliability statistic of this study. It shows that, all of the variables were tested for Cronbach's alpha and the values for all dimensions range from 0.626 to 0.874 . Therefore, the Cronbach's alpha reliability coefficient was accepted.

D. Answering Research Question 1: What are the Scores for Dimensions of Learning Organization Among Academicians?

TABLE IV: DIMENSIONS OF LEARNING ORGANIZATION AMONG

\begin{tabular}{lcc}
\multicolumn{2}{c}{ ACADEMICIAN } \\
\hline \hline LO's Dimensions & Mean & $\begin{array}{c}\text { Standard } \\
\text { Deviation }\end{array}$ \\
\hline $\begin{array}{l}\text { Continuous learning } \\
\text { Promote dialogue \& }\end{array}$ & 3.58 & 0.64 \\
Inquiry & 3.44 & 0.65 \\
Encourage & & \\
collaboration \& team & 3.08 & 0.73 \\
learning & & \\
Embedded system & 3.41 & 0.68 \\
Empowerment & 3.37 & 0.71 \\
$\begin{array}{l}\text { Environment } \\
\text { connection }\end{array}$ & 3.62 & 0.62 \\
Strategic leadership & 3.72 & 0.59 \\
\hline \hline
\end{tabular}

Table IV, shows the overall summary of descriptive statistic for the seven dimensions of learning organization among academician at UiTM, Puncak Alam. It was found that, strategic leadership was the most practised dimensions by the academician with mean 3.72 and standard deviation (SD) .59. The least dimension was collaboration and team learning with score means 3.08 and SD .73. 
Table V shows overall summary of strategic leadership. The highest score for strategic leadership was leaders ensure continually look opportunities to learn with mean score was 3.81. While, the lowest mean score was the leader empower others to help carry out the organization's value with the mean score 3.55 .

\begin{tabular}{|c|c|c|}
\hline Strategic Leadership & Mean & $\begin{array}{l}\text { Standard } \\
\text { Deviation }\end{array}$ \\
\hline $\begin{array}{l}\text { In my organization, leaders } \\
\text { generally support requests } \\
\text { for learning opportunities } \\
\text { and training. }\end{array}$ & 3.71 & .874 \\
\hline $\begin{array}{l}\text { In my organization, leaders } \\
\text { share up to date } \\
\text { information } \\
\text { employees about industry } \\
\text { trends and organizational } \\
\text { direction. }\end{array}$ & 3.74 & .884 \\
\hline $\begin{array}{l}\text { In my organization, leaders } \\
\text { empower others to help } \\
\text { carry out the organization's } \\
\text { vision. }\end{array}$ & 3.55 & .846 \\
\hline $\begin{array}{l}\text { In my organization, leaders } \\
\text { mentor and coach those } \\
\text { they lead. }\end{array}$ & 3.70 & .766 \\
\hline $\begin{array}{l}\text { In my organization, leaders } \\
\text { ensure continually look for } \\
\text { opportunities to learn. }\end{array}$ & 3.81 & .710 \\
\hline
\end{tabular}

\section{E. Answering Research Question 2: What is the Level of} Job Satisfaction among Academicians?

\begin{tabular}{|c|c|c|}
\hline Job Satisfaction & Mean & $\begin{array}{l}\text { Standard } \\
\text { Deviation }\end{array}$ \\
\hline $\begin{array}{l}\text { The freedom to use my } \\
\text { own judgement. }\end{array}$ & 3.75 & .665 \\
\hline $\begin{array}{l}\text { The way I was noticed } \\
\text { when done a good job. }\end{array}$ & 3.58 & .968 \\
\hline $\begin{array}{l}\text { The chance to do new and } \\
\text { original things from time } \\
\text { to time. }\end{array}$ & 3.68 & .762 \\
\hline $\begin{array}{l}\text { The chance to do different } \\
\text { things from time to time. }\end{array}$ & 3.69 & .834 \\
\hline $\begin{array}{l}\text { The recognition I get for } \\
\text { the work I did. }\end{array}$ & 3.58 & .952 \\
\hline $\begin{array}{l}\text { The chance to develop } \\
\text { new and better ways to do } \\
\text { the job. }\end{array}$ & 3.69 & .808 \\
\hline $\begin{array}{l}\text { The personal relationship } \\
\text { between my supervisor } \\
\text { and his/her employees. }\end{array}$ & 3.76 & .727 \\
\hline $\begin{array}{l}\text { The feeling of } \\
\text { accomplishment I get } \\
\text { from the job. }\end{array}$ & 3.84 & .803 \\
\hline
\end{tabular}

As depicted in the Table VI, it shows that the overall summary of the level of job satisfaction among academician at UiTM Puncak Alam. The results indicates that the feeling of accomplishment they get from the job was the highest score with mean score $(\mathrm{M}=3.84 ; \mathrm{SD}=.803)$ while the least score were the way they are noticed when they did a good job and the recognition they get for the work they do $(\mathrm{M}=3.58)$.
F. Answering Research Question 3: What is the Relationship between Learning Organization Practices and Job Satisfaction among Academician?

In answering research question 3, the relationship between dimensions of learning organization and job satisfaction was investigated using Pearson Product Moment Correlation Coefficients with simple bivarate correlation. It was found that, continuous learning was significantly correlated with job satisfaction with a moderate degree of correlation $(r=.589$, $p=000)$. Promote dialogue and inquiry also indicates the moderate relationship with the correlation score $(r=.555$, $p=.000$ ). Meanwhile, there was no significant relationship between collaboration and team learning with $(r=.67$, $p>0.05$ ). Besides, it was found that embedded system was significantly correlated with job satisfaction with a low degree of correlation $(r=.395, p=.000)$. Again, the data also portrays that, empowerment and environment connection were significantly correlated with satisfaction with a moderate degree of correlation $(r=.558, p=.000 ; r=519$, $p=.000)$ respectively. Lastly, strategic leadership indicates that there was a significant relationship with job satisfaction with a moderate degree of correlation $(r=.659, p=.000)$. (See Table VII)

TABLE VII: HYPOTHESES OF THE STUDY

$\mathrm{H}_{1}$ : There is a positive relationship between continuous learning and job satisfaction.

$\mathrm{H}_{2}$ : There is a positive relationship between inquiry and dialogue and job satisfaction.

$\mathrm{H}_{3}$ : There is a positive relationship between collaboration and team learning and job satisfaction.

$\mathrm{H}_{4}$ : There is a positive relationship between embedded system and job satisfaction.

$\mathrm{H}_{5}$ : There is a positive relationship between empowerment and job satisfaction.

$\mathrm{H}_{6}$ : There is a positive relationship between environment connection and job satisfaction.

$\mathrm{H}_{7}$ : There is a positive relationship between strategic leadership and job satisfaction.

Besides that, multiple regression was used to validate the bivarate result that being used as diagnostic tools. Result from multiple regressions was used to answer the hypotheses as above. The results of multiple regression on learning organization practices and job satisfaction shows the $F$ value was significant $(F=27.323, p=.000)$. The $F$ value actually explained the ratio between regression and residual. For this study, the regression equation was significant with the independent variables accounting for about $60.3 \%$ of the total variance $\left(R^{2}=.603, p=.000\right)$. It was means that, $60.3 \%$ of the variance in the job satisfaction has been explained by the dimensions of learning organization.

Of all seven variables, strategic leadership with value $(\beta$ $=.366, p=.000$ ) was the most significant predictor of overall job satisfaction, followed by continuous learning $(\beta=.366, p$ $=.000)$, environment connection $(\beta=.191, p=.007)$ and encourage collaboration and team learning $(\beta=.101, p$ $=.088$ ). Therefore, the hypothesis number 1,3,5,6 and 7 were accepted. Apart from that, promote dialogue and inquiry $(\beta$ $=.068, p=.4270$ and embedded system $(\beta=0.32, p=.636)$ 
were not significantly correlated to overall job satisfaction. Therefore, the hypothesis number 2 and 4 were rejected.

\section{REFERENCES}

[1] P. Senge, The Fifth Discipline: The Art and Practice of the Learning Organization, New York: Doubleday, 1990.

[2] R. Karash. Learning Organization - Organization Dialogue on Learning Organization. (2001). [Online]. Available: www.Karash.com.

[3] J. P. Crank, A. L. Giacomazzi, and B. Steiner, Building Tools for a Learning Organization: Assessing the Delivery of Community Policing Services in a Non-urban Setting, 2004.

[4] K. E. Watkins and V. J. Marsick, "In action, creating the Learning Organization," American Society for Training and Development, Alexandria, Los Angeles, 1996.

[5] K. E. Watkins and V. J. Marsick, "Make learning count! Diagnosing the learning culture in organizations," Advances in Developing Human Resources, vol. 5, no. 2, 2003.

[6] B. Phillips, "A four-level learning organization benchmark implementation model, Learning Organization, vol. 10, no. 2, pp. 98 $105,2003$.

[7] B. Sugarman and L. College. Learning, Working, Managing, Sharing: The New Paradigm of the Learning Organization. [Online]. Available: $\mathrm{http} / / / \mathrm{www}$. lesley.edu/journals/jppp/2/sugarman.html

[8] E. D. Nakpodia, Managing Conflict in Nigerian Universities, West Afr. J. Res. Dev., Edu., vol. 9, no. 2, 2003.

[9] R. W. Rowden and J. Conine, "The impact of workplace learning on job satisfaction in small US commercial banks," Journal of Workplace Learning, vol. 17, no. 4, pp. 215 - 230, 2005.

[10] R. Weathersby and J. White, "Ethics and community in management education," Academic Exchange Quarterly, vol. 8, no.1, pp. 229-333, 2004.

[11] E. D. Nakpodia, "The concept of university as learning organization: Its functions, techniques and possible ways of making it effective," Journal of Public Administration and Policy Research, vol. 1, no. 5, pp 079-083, 2009.

[12] R. Gaita, "Truth and the idea of a university," Journal of Australian University Review, pp. 13-18, 1997.

[13] P. McClenaghan, "The Vice-Chancellor as CEO: Corporate Manager, Transformational Leader or Academician?" in Proc. of HERDSA Conference Proceedings, Compact Disc, Auckland New Zealand, July $9^{\text {th }}, 1998$, pp. $1-15$.

[14] P. Ramsden, "Learning to lead in Higher Education," London: Routledge, 1998.

[15] E. Martin, "Changing academic work," Developing the Learning University. Buckingham: SRHE/ Open University, 1999.

[16] A. Agho, J. Price, and C. Mueller, "Determinants of Employee Job Satisfaction: An Empirical Test of a Casual Model," Human Relations, vol. 46, no. 8, pp. $1007-1027,1993$.
[17] S. McShane, M. Olekalns, and T. Travaglione, "Organizational behaviour: Emerging knowledge," Global Insight, $4^{\text {th }}$ ed. McGraw Hill Australia Pty Limited, 2013

[18] R. W. Rowden, and J. Conine, "The impact of workplace learning on job satisfaction in small US commercial banks," Journal of Workplace Learning, vol. 17, no. 4, pp. 215-230, 2005.

[19] T. M. Egan, B. Yang, and K. R. Bartlett, "The effects of organizational learning culture and job satisfaction on motivation to transfer learning and turnover intention," Journal of Human Resource and Development Quarterly, vol. 15, no. 3, pp. 279-301, 2004.

[20] A. Wilson and J. Frimpong, "A reconceptualisation of the satisfaction-service performance thesis," Journal of Service Marketing, vol. 18 , no. 6, pp. $471-481,2004$.

[21] K. M. Dirani, "Measuring the learning organization culture, organizational commitment and job satisfaction in the Lebanese banking sector," Journal of Resource Development International, 2009.

[22] D. J. Weiss, R. V. Dawis, G. W. England, and L. H. Lofquist. "Manual for the Minnesota Satisfaction Questionnaire," Minneapolis: University of Minnesota, Industrial Relations Center, 1967.

[23] S. J. Coakes and L. Steed, SPSS: Analysis without anguish version 14.0 for window analysis, $1^{\text {st }}$ ed., Singapore: John Wiley \& Sons Australia Ltd., 1997.

[24] U. Sekaran, Research Methods for Business: A Skill-building Approach, $4^{\text {th }}$ ed., New Delhi: John Wiley and Sons, 2006.

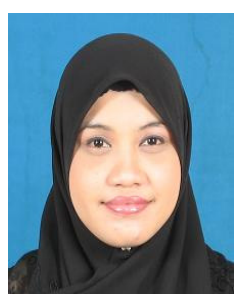

Murni Zarina Mohamed Razali is a lecturer at the faculty of business management in University Technology Mara Malaysia. She received her B.A (Hons) in international business management from University Technology Mara in 2005, and her master in business administration (MBA) from the same university in 2008. Her research interests include learning organization, job satisfaction and other management area.

Nurul Aufa Amira was a student of master in office management system that graduated in year 2012. Before that, she received her bachelor (Hons) in office management system in 2009 at University Technology Mara. Currently, she holds a position as administrative officer at implementation coordination Unit, Prime's Minister Department of Malaysia.

Nor Diyana Mohammed Shobri is a lecturer at faculty of business management in University Technology Mara Malaysia. Before joining UiTM, she was a lecturer at International Islamic College, Malaysia. She received her B.A (Hons) in Marketing in University Technology Mara Malaysia in year 2004 and her Master in Business Administration (MBA) from the same university in year 2006. Her research interests include customer service, service satisfaction and other management area. 